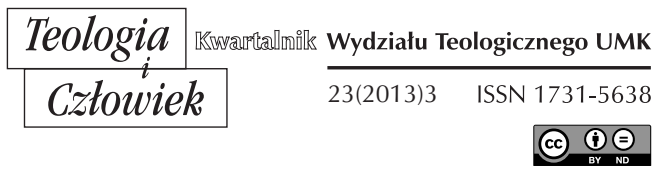

KS. ROBERT J. WOŹNIAK

KRAKÓW

\title{
WIARA PONOWOCZESNA. PRZYPADEK SLAVOJA ŽIŽKA
}

DOI: http://dx.doi.org/10.12775/TiCz.2013.034

Slavoj Žižek (ur. 1949), słoweński filozof, socjolog i krytyk kultury ${ }^{1}$, należy do najbardziej radykalnych i szokujących myślicieli ponowoczesności. Określa sam siebie jako prawdziwego marksistę². Jego twórczość charakteryzuje się często niepoukładanym pomieszaniem wątków filozofii (szczególnie Heglowskiego rodowodu), Lacanowskiej psychoanalizy ${ }^{3}$ i teologii judeochrześcijańskiej. Trzeba zwrócić uwagę, już na samym wstępie, na konkretny problem w lekturze Žižkowych tekstów, w których dominują niewytłumaczone, nieopisane chaotyczne przejścia od refleksji psychoanalitycznej do teologicznej i kulturoznawczej. Mikrokosmos wolnych skojarzeń i dygresji, nad którym panuje (jeśli w ogóle!) jedynie autor, nie pozwala dokonywać - jak się to często zdarza u myślicieli ponowoczesnych - łatwych, uproszczonych syntez analizowanego materiału.

* Ks. dr hab. Robert J. Woźniak - adiunkt w Katedrze Antropologii Teologicznej na Wydziale Teologicznym Uniwersytetu Papieskiego Jana Pawła II w Krakowie.

${ }^{1}$ Dobre, wstępne i syntetyczne opracowanie wizji Žižka można znaleźć w: B. Kuźniarz, Goodbye Mr. Postmodernism. Teorie społeczne myślicieli późnej lewicy, Toruń 2011, s. 315-410.

2 S. Žižek, O wierze, Warszawa 2008, s. 11.

3 A. Kotsko, Žižek and Theology, London-New York 2008, s. 13nn. 
W tym rizome sensów i znaczeń Žižek przykłada szczególną wagę do chrześcijaństwa, twierdząc, że należy je ocalić, gdyż jest zbyt cenne. Wydaje się, że to przeświadczenie ma wiele wspólnego z jego własnym rozumieniem fenomenu chrześcijańskiej wiary. Niniejszy przyczynek stawia sobie za zadanie próbę opisu Žižkowego rozumienia aktu wiary, następnie wskazanie na powody, dla których słoweński autor utrzymuje wagę chrześcijaństwa oraz diagnozę całości z perspektywy klasycznej analizy wiary.

\section{PRÓBA NIE DO KOŃCA MOŻLIWEJ SYNTEZY: ŽlŽEK À LA MILBANK}

Zanim przejdziemy dalej, warto poczynić jeszcze jedną wstępną uwagę podyktowaną swoistym charakterem pisarskiej działalności Žižka. Jako małe wprowadzenie do jego myślenia, przyda się przytoczyć próbę Johna Milbanka podania syntezy głównych wątków, motywów i zamierzeń Žižka4 . Milbank wymienia sześć głównych punktów quasi-systemu słoweńskiego filozofa: (1) ponowoczesność jest przedłużeniem nowożytności, (2) jej charakter postmetafizyczny wynika z wydoskonalenia metafizyki w Heglowskim rozumieniu, (3) nowożytność jest Heglowskiej natury i dlatego jest wynalazkiem kultury Zachodu i chrześcijaństwa, (4) nowożytny uniwersalizm jest chrześcijańskiej natury, (5) związek nowożytności i chrześcijaństwa opiera się na mutacji tego ostatniego widocznej w późnośredniowiecznym przełomie teologiczno-filozoficznym (od Eckharta przez Lutra aż do Boehme) i w końcu, (6) legitymacja nowożytności domaga się wypracowania chrześcijańskiego ateizmu opartego na marksistowskim materializmie (dialektycznym).

Główny punkt niezgody między Milbankiem a Žižkiem to rozumienie natury chrześcijaństwa: dla pierwszego jest ono paradoksem, dla drugiego dialektyką. Między tymi dwoma ujęcia zionie intelektualna przepaść. Zdaniem Milbanka właśnie owa dialektyczność autorskiej interpretacji chrześcijaństwa, obecnej w pracach słoweńskiego socjologa i filozofa, sprawia, że jego wizji nie można uznać za adekwatną w stosunku do rzeczywistości.

${ }^{4}$ J. Milbank, The Double Glory, or Paradox versus Dialectics: On Not Quite Agreeing with Slavoj Žižek, w: C. Davies (red.), The Monstrosity of Christ: Paradox or Dialectic?, Cambridge MA 2009, s. 111nn. 


\section{WSPÓŁCZESNA PROBLEMATYCZNOŚĆ WIARY: PUNKT WYJŚCIA ŽlŽKA}

Zainteresowanie Žižka wiarą zbudowane jest na gniewie z powodu zupełnego zapoznania istoty wiary we współczesności ${ }^{5}$. Žižkowa pasja do zajmowania się wiarą wynika z jego fundamentalnego oburzenia spowodowanego brakiem spójnej, nowożytnej teorii wiary.

Już we wstępie swojej książki $O$ wierze Žižek zauważa istotne pęknięcie we współczesnym przeżywaniu wiary. Dzisiaj „trzeba udawać, że się nie wierzy, tzn. otwarte publiczne wyjawienie czyjejś wiary uchodzi za bezwstyd, ekshibicjonizm". Być może taka matryca, paradygmat postępowania społecznego nie wydawałaby się niczym dziwnym, gdyby nie fakt, że

ukryta, odwrotną stroną [zauważonego] oporu jest to, że w rzeczywistości nikt nie uchodzi wierze - co zasługuje na podkreślenie zwłaszcza dziś, w naszych rzekomo bezbożnych czasach. W naszej oficjalnie ateistycznej, hedonistycznej, posttradycjonalnej kulturze świeckiej, w której nikt nie jest gotów publicznie przyznawać się do swojej wiary, fundamentalna struktura wiary jest tym bardziej wszeobecna - wszyscy skrycie wierzymy ${ }^{6}$.

Pierwotna postać wiary przybiera strukturę „fetyszystycznego Spaltung und Verleugnung", rozszczepienia i negacji (wiem, że nie ma wielkiego Innego, ale... skrycie wierzę w Niego). Žižek zauważa, że taki stan rzeczy ma swoje konsekwencje przede wszystkim $w$ apriorycznym odrzuceniu ateistycznej diagnozy wiary. Jako że wszyscy podświadomie (koniecznie) wierzą i że sama wiara jest składnikiem natury ludzkiej, prawo jej interpretacji przynależy jedynie tym, którzy do niej się przyznają: ateiści a priori nie mogą wysuwać przeciw wierze argumentów. Žižek nie zgadza się na taki stan rzeczy. W obliczu zauważonej struktury wiary (rozszczepienie i negacja) okazuje się, że przystęp do niej może mieć jedynie psychonalityk, ten jedyny ateista już na mocy fundującej psychoanalizę negacji Innego. Aby zrozumieć wiarę, trzeba powrócić do niej, zredukować ją do jej struktury symbolicznej.

${ }^{5}$ Z punktu widzenia teologii katolickiej, przybliżony i ogólny opis obecnej sytuacji wiary można znaleźć w: K. Ruhstorfer, Glaube im Aufbruch. Katholische Perspektiven, Paderborn 2013, s. 13-44.

${ }^{6}$ S. Žižek, $O$ wierze, s. 9. 
Właśnie z tego powodu Žižek odrzuca współczesny, ponowoczesny renesans religijny jako fałszywy. W tym duchu krytykuje nawrót to tendencji gnostyckich widocznych $\mathrm{w}$ zbliżeniu cybertechniki i religii. Podobnie sceptycznie odnosi się do prób przeszczepiania buddyzmu na zachód. We wszystkich tych postaciach odnowy religijnej następuje, jego zdaniem, prymitywny powrót do wiary ujętej poza strukturą symboliczną. W tym 'duchowym disnaylendzie' przedmiotem zainteresowania słoweńskiego filozofa staje się chrześcijaństwo, które, jego zdaniem, jest religią najbardziej odpowiednią do ujęcia symbolicznej natury wiary.

\section{IKONOKLAZM JAKO PIERWOTNE ODSŁONIĘCIE NATURY WIARY}

Žižek zmierza do wyciagnięcia na światło dzienne ukrytej natury wiary odwołując się do zgrabnie skrojonej analizy ikonoklazmu. Jest ona na tyle interesująca, iż warto przyjrzeć się jej z większą uwagą. Na kartach podstawowego dla opisu Žižkowego rozumienia wiary $O$ wierze odnajdujemy taką oto analizę żydowskiego zakazu czynienia obrazów:

Co zatem z deklarowanym przez Żydów bezwarunkowym obrazoburczym monoteizmem: Bóg jest Jednym, całkowicie Innym, bez ludzkiej formy? Typowy pogląd powiada, że pogańscy (tzn. przedżydowscy) bogowie byli antropomorficzni [...] podczas gdy religia żydowska ze swoim obrazoburstwem pierwsza zupełnie "odantropomorfizowana" boskość. Może jednak jest właśnie na odwrót? Może potrzeba zakazania człowiekowi tworzenia sobie obrazów Boga świadczy o „personifikacji” Boga występującego w "uczyńmy człowieka na Nasz obraz, podobnego Nam" (Rdz 1,26), a prawdziwym celem żydowskiego ikonoklazmu nie są wcześniejsze religie pogańskie, lecz raczej własna „antropomorfizacja” / „personalizacja” Boga przez judaizm? Może religia żydowska sama wytwarza ten nadmiar/eksces, którego ma zabraniać? To żydowski Bóg jest pierwszym Bogiem w pełni „spersonalizowanym”, Bogiem, który mówi ,jestem, który jestem"

${ }^{7}$ Warto zwrócić uwagę, że we współczesnej teologii katolickiej pojawiają się coraz częściej odwołania do ikonoklazmu i to z punktu widzenia teologii trynitarnej. Zob. G. Neuhaus, Fundamentaltheologie: Zwischen Rationalitäts- und Offenbarungsanspruch, Regensburg 2013, s. 219-221.

${ }^{8}$ S. Žižek, $O$ wierze, s. 217-218. 
Centralnym punktem powyższej argumentacji jest teza, że „wraz z judaizmem Bóg ulega petnej "antropomorfizacji”, a spotkanie z Nim staje się spotkaniem $\mathrm{z}$ inną osobq w najpełniejszym sensie tego słowa" ${ }^{\prime \prime}$. To właśnie owa antropomorfizacja stanowi istotny moment wspomnianego w tekście nadmiaru/ekscesu, przeciw któremu zwraca się ikonoklazm. Bezpośrednim skutkiem takiego ujęcia jest podstawowy dla Žižka fakt, że „antropomorfizacja i obrazoburstwo nie są prostymi przeciwieństwami"10. Judaizm, odkrywając radykalny związek między Bogiem i człowiekiem, związek odsłaniający siebie $\mathrm{w}$ antropomorficznej, osobowej koncepcji bóstwa, doprowadza do niemożliwego do przeżycia doświadczenia nadmiaru w samej koncepcji człowieka. Ikonoklazm stanowi jeden z podstawowych mechanizmów wiary żydowskiej, poprzez który pozbywa się on przeczucia antropologicznego nadmiaru własnej koncepcji boskości.

W przeciwieństwie do pogan Żydzi uważali/zakładali, że (zmysłowy/ materialny) obraz osoby boskiej pokazałby zbyt wiele, uwidaczniając jakąś straszną tajemnicę, która powinna raczej pozostać w ukryciu. To dlatego musieli go zakazać - żydowski zakaz ma sens tylko w kontekście tej obawy, że obraz odsłoni coś wstrząsającego, że w jakiś nie do zniesienia sposób będzie prawdziwy i adekwatny ${ }^{11}$.

Ikonoklazm jest rodzajem wyparcia prawdy o organicznie powiązanych ze sobą tożsamościach Boga i człowieka. Innymi słowy, jest on ucieczką od prawdy o tych tożsamościach i o ich radykalnie organicznym związku. W Žižkowej interpretacji, ikonoklazm żydowski rodzi się z lęku przez prawdą.

Zauważmy, że wyparcie, o którym mowa, jest całkiem innego rodzaju (jeśli nawet nie morfologicznie to przynajmniej genetycznie) niż te, których resentymentalne wersje odnajdujemy u mistrzów podejrzeń. Wiara u Žižka nie powstaje z resentymentu, z braku, ale z nadmiaru. Człowiek uświadamia sobie, ze nosi w sobie cząstkę Boga. Owa cząstka, niestety, nie pozwala mu osiągnąć pełnej autoidentyfikacji, tożsamości:

Nie będąc wcale niczym najwyższym w człowieku, wymiarem czysto duchowym, do którego dążyłby cały człowiek, "boskość” jest raczej niejaką przeszkodą, „kością w gardle”, czymś, owym niezgłębionym X,

\footnotetext{
9 Tamże, s. 219.

10 Tamże.

11 Tamże, s. 223.
} 
z powodu którego człowiek nie może stać się w pełni człowiekiem, stać się tożsamy z sobą. Nie chodzi o to, że z racji ograniczeń swojej śmiertelnej, grzesznej natury człowiek nie może stać się w pełni boski, lecz o to, że $\mathrm{z}$ powodu Bożej iskierki w nim, nie może stać się w pełni człowiekiem ${ }^{12}$.

Nie można nie ulec wrażeniu, że Žižkowa koncepcja wiary związana jest organicznie $\mathrm{z}$ istotną metodą całej myśli ponowoczesnej, jaką jest od czasów Nietzschego, Heideggera i Derridy dekonstrukcja. Powyższe teksty pokazują wyraźnie, że Žižek dokonuje mocnej dekonstrukcji jej treściowej zawartości i formalnej struktury. Z punktu widzenia metodologicznego, przez dekonstrukcję autor $O$ wierze rozumie: „dwa zakazy: [dekonstrukcjonizm] zabrania "naiwnego" podejścia empirycystycznego i globalnych, niehistorycznych tez metafizycznych o początkach i strukturze wszechświata"13. Ten podwojony zakaz, odniesiony do żydowskiej wiary ujawnia w niej wspomniany powyżej lęk przed nadmiarem, przed prawdą tożsamości człowieka. Pierwotne słowo Žižka o wierze to konieczność jej radykalnej dekonstrukcji, za którą kryje się przekonanie o jej skomplikowanej strukturze znaczeniowej. W przypadku wiary żydowskiej, mamy do czynienia z rzeczywistością ukrywania, wypierania prawdy. Związek wiary żydowskiej z ikonoklazmem nie jest tu przypadkowy: właśnie w nim i poprzez niego można odkryć ukryty, przemilczany rdzeń wiary judaistycznej w postaci wyparcia nadmiaru antropologicznego. Wiara i ikonoklazm w judaizmie pozostają $\mathrm{w}$ nierozdzielnym związku: ikonoklazm odsłania to, co w judaistycznej wierze jest najistotniejsze, czyli próbę ukrycia, oddalenia budzącego grozę przeczucia antropologicznej nadwyżki transcendencji. $\mathrm{W}$ tej odsłonie wiara pozostaje wyparciem, ucieczką, zamknięciem oczu, albo dokładniej: zakazem tworzenia obrazów boskości, za którym stoi przeczucie, z którym człowiek nie potrafi sobie jeszcze poradzić. Niejasnym, wypieranym tematem tego przeczucia jest własna tożsamość człowieka.

\section{DLACZEGO NALĖ̇Y OCALIĆ CHRZEŚCIJAŃSTWO?}

Wiara Żydów okazuje się, w ten sposób, jedynie etapem w globalnych dziejach wiary. Zgodnie $\mathrm{z}$ diagnozą Milbanka ${ }^{14}$, materialistyczna

12 Tamże, s. 168.

13 Tamże, s. 60.

14 J. Milbank, dz. cyt., s. 176-216. 
teologia Žižka opiera się na Heglowskiej dialektyce i jest, w istocie rzeczy, walką o dialektyczną koncepcję chrześcijaństwa. Częścią tej dialektyki jest antytetyczność wiary pogańskiej i żydowskiej zniesiona w wierze chrześcijańskiej.

Dialektykę widać jak dłoni w przypadku Žižkowej hermeneutyki relacji między judaizmem a chrześcijaństwem. Chrześcijańska koncepcja wiary dialektycznie dekonstruuje żydowską jej formę.

Przejście od judaizmu do chrześcijaństwa to ścieżka prowadząca od dekonstrukcji i demistyfikacji judaistycznej wiary do wiary ujętej w chrześcijaństwie jako dekonstrukcja. W zasadzie wygląda na to, że dekonstrukcyjne zabiegi są dla Žižka samą czysta wiarą w jej dekonstruującej istocie i że wcześniej opisana dekonstrukcja wiary judaistycznej dokonana jest $\mathrm{z}$ perspektywy dekonstruującego charakteru wiary chrześcijańskiej. Innymi słowy, chrześcijańska wiara staje się dialektyczną dekonstrukcją wiary żydowskiej, rodzajem przezwyciężenia jej antytetycznego względem wiary pogańskiej charakteru, uwznioślającym zniesieniem (Heglowskie Aufhebung) ich obu. Przy czym, twierdzi Žižek, w procesie opisywanej dekonstrukcji tym, co ulega zmianie, jest przede wszystkim zagubiona wcześniej prawdziwa tożsamość człowieka:

Przy przejściu od judaizmu do chrześcijaństwa to nie zawartość się zmienia (status Boga), lecz głównie tożsamość samego wiernego, a zmiana w Bogu (już nie transcendentnym Innym, lecz Chrystusie) stanowi refleksyjne określenie tej zmiany ${ }^{15}$.

Na czym polega wspomniana w powyższym fragmencie 'zmiana tożsamości wiernego'? W istocie rzeczy jest ona dekonstrukcją i konstruktywną asymilacją tego, co dla Żydów było nie do przyjęcia: antropologicznego charakteru transcendencji. Žižek docenia wiarę chrześcijańską, gdyż jest ona dla niego podstawową siłą dekonstruującą zarówno pogańskie wersje religijności, jak i ich żydowską antytezę. Wiara chrześcijan, ześrodkowana na przeżyciu agape, stanowi twórcza siłę emancypacyjną: uwalnia ona od obciążającego i blokującego człowieka doświadczenia nadmiaru. Jednocześnie to ona właśnie skierowuje całą uwagę na materialność realności, na jej jedyność i, w konsekwencji, na brak jakiegokolwiek Spoza. Rozważmy następujący teksty:

${ }^{15}$ S. Žižek, dz. cyt., s. 227. 
Zgodnie z obiegową opinią poganie byli antropomorficzni, Żydzi radykalnie obrazoburczy, a chrześcijaństwo miałoby urzeczywistnić swego rodzaju „syntezę”, częściowy powrót do pogaństwa przez wprowadzenie „ikony” cierpiącego Chrystusa jako „wymazującej wszelkie ikony”. Wbrew temu potocznemu poglądowi trzeba stwierdzić, że to religia żydowska pozostaje „,abstrakcyjną/bezpośrednią” negacją antropomorfizmu i jako taka jest z nim związana, określona przezeń w jego bezpośredniej negacji, i tylko chrześcijaństwo de facto „znosi” religie pogańskie. Stanowisko chrześcijańskie opiera się na takim oto poglądzie: zamiast zabraniać obrazowania Boga, może właśnie na to pozwolić i przedstawić go jako jeszcze jeden ludzki byt, jako ułomnego człowieka nieodróżnionego pod względem swych istotowych właściwości od innych ludzi? ${ }^{16}$

Žižkowa analiza przejścia od wiary judaistycznej do chrześcijańskiej jest w istocie rzeczy, opartą na swoiście interpretowanej prawdzie wcielenia, dekonstrukcją klasycznie rozumianej zawartości wiary, szczególnie jej sfery referencyjnej. Jest, aby posłużyć się metaforą Žižka, pewnego rodzaju wypróżnieniem. Idzie o wypróżnienie polegające na przyswojeniu prawdy własnej tożsamości bez konieczności ucieczki przed nią w świat hipostazowania jakiegoś Spoza. Wierzyć po chrześcijańsku oznacza wyzbyć się pokusy projektowania przeczucia głębi własnej tożsamości na świat transcendencji. Przy czym, Žižek podkreśla, że nie proponuje tym samym rezygnacji $z$ transcendencji, a jedynie nowe jej ujęcie. Dekonstrukcja wiary, jaką jest chrześcijaństwo, nie proponuje uchylenia transcendencji, lecz uczynienie jej dostępną „w tej niezdarnej i żałosnej istocie, którą kocham”17. W ten sposób tylko ono „potrafi zupełnie zrezygnować z potrzeby obscenicznego suplementum. Nie ma tajnego tekstu towarzyszącego Ewangelii jako cień superego"18.

Kluczowym argumentem Žižka za jego rozumieniem wiary chrześcijańskiej jako dekonstrukcji diady pogańsko-żydowskiej w jej dialektycznym uchylaniu transcendencji jest psychoanalityczno-kulturowa analiza chrystologii. Analiza ta przeprowadzana jest w dwóch kierunkach: po pierwsze dotyczy ona treściowej zawartości wydarzenia wcielenia kulminowanego w śmierci Chrystusa oraz, po drugie, za przedmiot swój obiera imperatyw naśladowania miłości Chrystusa wyrażonej w jego wcieleniu i pozostawionej jako paradygmat postępowania, nowej etyki.

16 Tamże, s. 220-222.

17 Tamże, s. 167.

18 Tamże, s. 235. 
Skupmy się jednak na pierwszym ze wspomnianych aspektów. Žižek zapisuje:

Chrystus - pisze Žižek - jest w pełni człowiekiem tylko o tyle, o ile bierze na siebie nadmiar/resztę, owo „zbyt wiele”, ze względu, na które człowiek, ścisłe biorąc, nigdy nie jest w pełni człowiekiem. Jego formułą nie jest Człowiek $=$ Bóg, lecz człowiek = człowiek, gdzie wymiar boski interweniuje tylko jako owo "coś" przeszkadzającego człowiekowi w pełnej identyfikacji z sobą. W tym sensie pojawienie się Chrystusa faktycznie reprezentuje śmierć Boga. Uwidacznia, że Bóg jest tylko nadmiarem człowieka, owym „za wiele" życia niedającym się zawrzeć w żadnej formie życia i naruszającym kształt (morfe) antropomorfizmu ${ }^{19}$. Chrystus jako człowiek = Bóg to jedyny wypadek pełnego człowieczeństwa (ecce homo, jak Poncjusz Piłat woła do tłumu żądającego uśmiercenia Chrystusa). Dlatego po jego śmierci nie ma miejsca dla żadnego Boga Spoza ${ }^{20}$.

Chrystus musi umrzeć nie po to, by umożliwić bezpośrednią komunikację Boga z ludzkością, lecz dlatego, że nie ma już transcendentnego Boga jako celu komunikacji21.

To chrześcijaństwo jest w swej istocie, wiarą, która demistyfikuje świat Spoza, zwracając uwagę, dzięki postaci wcielonego, cierpiącego, kruchego Absolutu22, na ostateczność materialnego świata. Wiara chrześcijańska, określając swoją chrystologiczną treścią sam akt wiary, jest dziejową formą seansu psychoanalitycznego, który pozwala ludzkości całkiem po marksistowsku - zwrócić się tylko do realności kontyngencji, czyniąc ją jedyną istniejąca transcendencją ${ }^{23}$. Co więcej, w jednym i tym samym seansie zostaje zmieciony nie tylko gmach zaświatów ${ }^{24}$, trynitarna prawda wiary obrócona w czyste dzianie się świeckiej historii zbawienia ${ }^{25}$,

19 Tamże, s. 222.

${ }^{20}$ Tamże, s. 168.

${ }^{21}$ Tamże, s. 34.

${ }^{22} \mathrm{~W}$ tym względzie bardzo ważne są Žižkowe rozważania na temat ofiary Chrystusa. Zob. tamże, s. 27-42.

${ }^{23} \mathrm{~W}$ istocie rzeczy, mamy tu do czynienia z powtórzonym i zmodyfikowanym argumentem Luca-Ferry'ego (1998). Istotna różnica polega na zastosowaniu, nieobecnej u Ferry'ego, perspektywy materialistycznej dialektyki marksistowskiej. Na ten temat również: M. Onfray, Traktat ateologiczny, Warszawa 2008.

${ }^{24}$ S. Žižek, dz. cyt., s. 168-169.

${ }^{25}$ Tamże, s. 32-34. „Pozostaje tylko Duch Święty, wspólnota wiernych, na którą przechodzi niezgłębiona aura Chrystusa, gdy zostaje pozbawiona swojej inkarnacji (lub, 
ale i podarowana absolutna wolność rozpoczynania wszystkiego od nowa, autonomicznego ustanawiania swojej własnej tożsamości i jej dziejów. Chrześcijaństwo jest największą rewolucją w świecie ludzkiej wolności: centralna w nim postać Chrystusa „nie zbawia ludzi bezpośrednio, lecz daje im możliwośćc ${ }^{26}$ zbawienia, pozbycia się nadmiaru" ${ }^{\prime 27}$. To pozbycie się nadmiaru, dokonuje się w wierze „w skoku wiary”, poprzez który człowiek decyduje się naśladować odwagę Chrystusa: przeżyć swoje życie, dobrowolnie przyjmując jego nadmiar bez rzutowania/przenoszenia go na jakąś figurę Innego ${ }^{28}$.

Jesteśmy teraz w stanie odpowiedź na główne pytanie: dlaczego warto zachować, ocalić chrześcijaństwo? Odpowiedź, jakiej udziela Žižek, jest następująca: właśnie z powodu dekonstrukcyjnego charakteru jego wiary ${ }^{29}$, która - jako działalność czysto demistyfikacyjna - pozwala na odzyskanie życia i wolności:

Tu wkracza „dobra nowina” chrześcijaństwa: cud wiary polega na tym, że jest możliwe przebycie tej fantazji, odwołanie tego podstawowego rozstrzygnięcia, rozpoczęcie własnego życia od nowa, od punktu zerowego - krótko mówiąc, zmiana całej wieczności (tego, czym „zawsze już jesteśmy”). „ponowne narodziny”, o których mówi chrześcijaństwo (wstępując do wspólnoty wiernych rodzi się na nowo), to nazwa na taki nowy początek. Wbrew pogańskiej/lub gnostyckiej mądrości celebrującej (ponowne) odkrycie czyjejś prawdziwej jaźni - powrót do niej, urzeczywistnienie jej możliwości itp. - chrześcijaństwo wzywa nas do zupełnego przeorientowania się. Kierkegaard miał rację: ostateczny wybór przebiega między Sokratejskim przypominaniem a chrześcijańskim powtórzeniem. Chrześcijaństwo każe nam powtórzyć fundujący gest pierwotnego wyboru. Chciałoby się sparafrazować 11. tezę Marksa o Feuerbachu:

ujmując to w terminach Freudowskich, gdy nie może już opierać się na ciele Chrystusa w takim samym sensie, w jakim dla Freuda popęd dąży do bezwarunkowego zaspokojenia zawsze musi się „opierać” na jakimś szczególnym, przygodnym obiekcie materialnym, który stanowi dla niego źródło zaspokojenia)". Tamże, s. 168.

${ }^{26}$ Žižek, za Kierkegaardem, rozumie „możliwość jako coś wyższego od rzeczywistości" (zob. tamże, s. 186). Słychać tu echo fundamentalnego przeświadczenia nowożytnej metafizyki przedkładającej byt możliwy nad byt realny.

27 Tamże, s. 185.

${ }^{28}$ Tamże, s. 186.

${ }^{29}$ Teza ta stanowi główną ideę książki Žižka zatytułowanej Kruchy absolut (2009), w której stawia sobie za przedmiot swojego dyskursu wywiedzenie rodowodu marksizmu z chrześcijaństwa. Ta genealogia skłania Žižka do stwierdzenia, iż obie formy społeczne powinny 'walczyć po tej samej stronie barykady'. 
„Filozofowie uczyli nas tylko odkrywania naszej prawdziwej jaźni, idzie jednak o to, aby ja zmienić". I to chrześcijańskie dziedzictwo, często zamazane, jest dziś cenniejsze niż kiedykolwiek ${ }^{30}$.

Na kartach pism Žižka chrześcijaństwo zostaje usprawiedliwione przez swoją rewolucyjną potencję. W tym względzie koncepcja autora $O$ wierze wpisuje się $\mathrm{w}$ cały katalog współczesnych prób dekonstrukcji chrześcijaństwa pod szczytnymi hasłami wyzwolenia świata z religijnego odniesienia do jakiejś, łudzącej powabami realności i obiektywności, transcendencji. Chrześcijaństwo jest wszak „religią odejścia od religii” ${ }^{31}$. Czy aby na pewno jednak taka interpretacja może zostać uznana, chociażby w części, za adekwatną?

\section{WNIOSKI: PONOWOCZESNA GNOZA}

Diagnoza Žižkowego ujęcia wiary wymaga odwołania się do i namysłu nad współczesnym kontekstem chrześcijańskiego roszczenia wyrażonego również $\mathrm{w}$ postaci konkretnego rozumienia natury, struktury i treści aktu wiary. Wzorcową analizę obecnego kontekstu wiary przedstawił Joseph-Marie Le Guillou OP w swojej książce Le Mystčre du Pčre.

Ostrze diagnozy Le Guillou staje się widoczne już w samym podtytule interesującego nas dzieła: Wiara apostołów i gnozy wspótczesne. Kluczową kategorią analizy współczesnego zagrożenia wiary staje się gnoza jako perwersyjna, zakłamująca interpretacja wiary. Le Guillou śledzi dzieje gnozy na przykładzie polemicznych, apologetycznych pism św. Ireneusza. Biskupowi Lyonu przypadło prowadzić szeroko zakrojoną walkę ze szturmem gnozy na młody Kościół. Zdaniem Le Guillou, podobny kryzys dotyka dzisiaj Kościoła. Jaka jest jego anatomia? Gnostyk utrzymuje, że wierzy w Boga. Jednak struktura jego aktu wiary wykazuje niepowstrzymane zakrzywienie ku sobie, ku podmiotowi. Już klasyczna i rozpowszechniona diagnoza istoty gnozy wskazuje, iż chodzi w niej o religijne samozbawienie dzięki autonomicznemu poznaniu. Gnostyk

${ }^{30}$ Tamże, s. 250

${ }^{31}$ Zob. wspomniane już dzieło Luca-Ferry'ego (1998). Na szczególną uwagę w tym względzie jednak zasługują tomy dekonstrukcji chrześcijaństwa napisane przez Nancy'ego (2005-2010). 
odrzuca zatem świadectwo apostolskie o boskim Objawieniu dokonanym w świece i jego historii dzięki 'dwóm rękom Ojca': Synowi i Duchowi Świętemu. W istocie rzeczy, wiara gnostyka jest autopozycją jego podmiotu, zagarniającego totalitarnie rzeczywistość dla siebie. W takim przypadku pod-miot, chwyta i rzuca pod siebie (pod-miot miota-pod siebie), poddaje sobie i swoim pojęciom całość rzeczywistości, roszcząc sobie prawo do bycia jej ostatecznym panem.

Na uwagę zasługuje fakt, że autor Le Mystčre dostrzega zarzewie i najbardziej podstawowe formy gnozy w kontekście wielkich totalitaryzmów, jakie dotknęły ostatni wiek. Komunizm może w tym względzie uchodzić za wielki gnostycko-utopijny plan sprowadzenia przesłania ewangelicznego tylko do realiów teraźniejszości. Komunistyczna utopia jest formą zeświecczonej soteriologii chrześcijańskiej².

Wydaje się, że przytoczone teksty Žižka i ich analizy wydają się dobrze wpisywać w klasyczną już diagnozę Le Guillou. Dotykamy tu pewnego rodzaju nieścisłości, towarzyszącej często rewolucyjnym myślicielom, którzy tak głęboko dekonstruują rzeczywistość, że sami wpadają w szpony krytykowanych przez siebie jej ujęć. Teksty Žižka świadczą o tym, że walcząc z gnozą sam w nią wpada. Chrześcijaństwo, jakie traktuje on $\mathrm{z}$ podziwem, jest $\mathrm{w}$ istocie rzeczy jego własnym wymysłem, efektem narzucenia na rzeczywistość własnej siatki pojęciowej.

Główny jej punkt to nieobecność referencjonalnego rozumienia wiary i sprowadzenie jej jedynie do struktury symbolicznej ${ }^{33}$. Žižek popełnia rudymentarny błąd redukcjonizmu, wtedy, kiedy w swoim milczącym, przyjętym a priori przedrozumieniu wiary redukuje ją jedynie do struktury immanentnej, podczas gdy klasyczna teologia rozróżnia od zawsze między obiektywnym i subiektywnym wymiarem aktu wiary ${ }^{34}$. Taki arbitralny redukcjonizm jest wyraźnym dowodem zwycięstwa sil-

${ }^{32}$ Widać tu wspólne punkty z de Lubackowskim odczytaniem trynitarnego utopizmu kalabryjskiego opata Joachima z Fiore oraz z jego próbą przedstawienia genealogii tzw. humanistycznego ateizmu. Zob. H. De Luback, La Postérité spirituelle de Joachim de Flore, Paris 1979; tenże, Dramat humanizmu ateistycznego, Kraków 2004.

${ }^{33}$ Podobne tendencje można odnaleźć w wielu pracach Drewermanna. Wspomnijmy chociażby wielotomową psychoanalityczną egzegezę biblijną Eugena Drewermanna, zatytułowaną globalnie Glauben in Freiheit.

${ }^{34} \mathrm{Ch}$. Böttigheimer, Glauben verstehen: Eine Theologie des Glaubensaktes, Freiburg, Basel, Wien 2012, s. 15, 57, 144-175; na temat aktu wiary (jego subiektywnej struktury): D. Hercsik, Der Glaube: eine katholische Theologie des Glaubensaktes, Würzburg 2007, s. 263-289. 
nego myślenia, które znów odnajduje swoją ostateczną podstawę w silnym podmiocie. Wiara stając się symbolem prowadzącym człowieka ku wnętrzu, przestaje być osobowym spotkaniem z prawdziwą innością Boga. W ten sposób ryzykuje ona niebezpieczną drogę zapaści podmiotu. Kiedy zanika wszelka prawdziwa (tzn. obiektywna) transcendencja, kiedy zostaje ona zredukowana jedynie do antropologicznego, symbolicznego klucza do ludzkiej wewnętrzności, musi, prędzej czy później zaniknąć i sam symbolizowany w niej podmiot. Dekonstrukcja realności transcendentnego odniesienia wiary prowadzi nieuchronnie do dekonstrukcji samego podmiotu, który traci najbardziej fundamentalnego dla siebie Dialoganta. W moim przekonaniu, opisywany brak świadomości personalistyczno-dialogicznej natury wiary chrześcijańskiej jest podstawowym błędem, który wiedzie Žižkowe interpretacje na manowce nietrafności. ${ }^{35}$ Wydaje się, jakby nasz autor w ogóle nie rozumiał owej podstawowej struktury wiary wyznaczonej przez dialogiczna relację realnych $\mathrm{Ja}$ i $\mathrm{Ty}^{36}$.

Pierwszy owoc wspomnianego, fundamentalnego nieporozumienia co do prawdziwej natury wiary wiedzie Žižka do przeświadczenia o związku wiary chrześcijańskiej i materializmu dialektycznego. Przerażający mariaż wiary i marksizmu skutkuje przekonaniem, że przejście przez doświadczenie chrześcijańskie, uczestnictwo w jego dziedzictwie jest warunkiem stania się materialistą. Ten materialistyczny moment systemu autora The Parallax View zapewne odsuwa jego pozycję od klasycznie ujętej gnozy, jednak $w$ istocie rzeczy stanowi jej zmutowaną formę. $\mathrm{W}$ istocie rzeczy $\mathrm{w}$ prawdziwym materializmie chrześcijańskim idzie nie tyle o dialektyczną koncepcję podboju rzeczywistości dla zaborczego podmiotu, ile o prawdę wiary głosząca, że droga do zbawienia wyznaczona jest przez drogę Boga do człowieka. Tajemnica wcielenia stanowi uwznioślenie materialnej struktury bycia świata. W tym ujęciu, materia jest drogą, środkiem wiodącym do celu, którym jest spotkanie Boga i człowieka. Tymczasem dla Žižka, materia jest swoistego rodzaju całością, zwartą i zamkniętą w sobie, samowystarczalną totalnością, która

${ }^{35}$ Dzisiaj często powraca się $\mathrm{w}$ szerszej debacie do tzw. problemu realizmu przekonań religijnych. Na ten temat warto zapoznać się z P. Sikora, Stowa i zbawienie. Dyskurs religijny w perspektywie filozofii Hilarego Putnama, Kraków 2004.

${ }^{36}$ J. Mouroux, Je crois en Toi: structure personnelle de la foi, Paris 1949; Ch. Böttigheimer, dz. cyt., s. 126-127. 
podlega władzy przekształcającego ją rewolucyjnie podmiotu, co stanowi istotę materializmu dialektycznego. Tym razem ów materializm wyłania się nie tyle ze scjentystycznej redukcji wszystkiego do materii, lecz z sprowadzenia całości rzeczywistości do psychoanalizy. W materializmie dialektycznym à la Žižek materia jest miejscem panowania podmiotu: oto zamierzona przez Žižka rewitalizacja niemieckiego idealizmu przez psychoanalizę Lacana $^{37}$. W tej misji, słoweński filozof podporządkowuje jej prawdę chrześcijaństwa, którego treść zostaje sprowadzona do odsłonięcia materialistycznej prawdy o śmierci Boga, wielkiego Innego (l'Autre n'existe pas). Przełomowym paradygmatem materializmu jest śmierć Chrystusa, jego krzyk opuszczenia z Krzyża, wieszczące, zdaniem Žižka, nieobecność Boga ${ }^{38}$. Wiara $\mathrm{w}$ tym wypadku jest otwarciem się na prawdę tej fundamentalnej nieobecności, drogą do niej i jej akceptacją. Tym samym staje się ona drogą do dialektycznego materializmu. Analityczne i założeniowe zaniedbanie personalistycznej natury aktu wiary chrześcijańskiej, opisane powyżej, podąża ręką w rękę ze wspomnianą opcją na rzecz dialektyki.

To wszystko skłania do jednoznacznego wniosku: Žižkowe analizy chrześcijańskiego fenomenu aktu wiary są radykalnie nieadekwatne i pozbawione obiektywizmu.

Streszczenie. Celem niniejszego artykułu jest prezentacja hermeneutyki fenomenu wiary chrześcijańskiej Slavoja Žižka. Przedmiotem analizy jest książka Žižka zatytułowana $O$ wierze, w której autor prezentuje jego oryginalne rozumienie istoty aktu wiary i jego zawartości. Głównym argumentem Žižka jest to, że wiara chrześcijańska jest pewnego rodzaju strategią dekonstrukcyjną, która pozwala uwolnić istotę ludzką od iluzji obiektywnej, rzeczywistej Transcendencji. Moja osobista krytyka zasadza się na fakcie jego analitycznego niedopatrzenia się teologicznej istoty wiary, mianowicie jej międzyosobowej, dialogicznej i ekstatycznej natury.

Słowa kluczowe: Žižek; teologia; wiara.

Abstract. Faith after modernity: a case of Slavoj Žižek. Present paper aims at presentation of Slavoj Žižek's own hermeneutics of the phenomenon of Christian faith. The subject of analyses is Žižek's book On faith, in which the author presents his original understanding of the essence of the act of faith and its contents. The

${ }^{37}$ M. Pound, Žižek: A Critical Introduction, Grand Rapids 2008.

${ }^{38}$ Ten moment systemu Žižka stanowi centrum opisu jego teologii w M. Pound, dz. cyt., s. 23-52. 
main argument of Žižek is that Christian faith is a kind of deconstructionist strategy, which allows to free human being from the illusion of objective, real Transcendence. My own critique of his position is grounded in the fact of his analytical negligence of the theological nucleus of faith, namely faith's interpersonal, dialogical and ecstatic nature.

Keywords: Žižek; theology; faith. 